\title{
In-vivo Histopathological Efficacy study of Hinguleshwar rasa and Indomethacin on FCA induced Rheumatoid Arthritis in Paw model of Rats
}

\author{
Research Article
}

\section{Ajay Bapusaheb Sonawane ${ }^{*}$, Archana P Gharote², Vikas V Karande ${ }^{3}$}

1. Ph.D Scholar, 2. Professor and HOD, Department of Rasashastra and Bhaishajya Kalpana, School of Ayurveda, D Y Patil deemed to be University, Navi Mumbai. 3. Assistant Professor, Department of Pharmacology and Toxicology, Krantisinh Nana Patil College of Veterinary Science Shirwal, Satara.

\begin{abstract}
As per Ayurveda symptoms of Rheumatoid arthritis resembles with Amavata disease. Action of Hinguleshwara rasa on Amavata is mentioned in the text of Rasatarangini in Ayurveda. In this study investigation was made to find out preventive \& curative changes occurred in rat paw of Freuds Complete Adjuvant induced RA model. Indomethacin was kept as standard control and Hinguleshwar rasa as a treatment. After induction of arthritis with FCA on day 14, animals were treated up to $28^{\text {th }}$ day of the study with indomethacin and Hinguleshwar rasa. After completion of 28 days of daily single oral dose administration of Hinguleshwar rasa and Indomethacin, animals were sacrificed. Ankle joints were severed and processed for histological studies. It was observed that the joints of Hinguleshwar rasa treated animals showed recovery towards normal histological architecture whereas all other joint samples of bones of rats were showing focal and minimal pathological changes, focal and minimal congestion of blood vascular tissue. Similar normal Histo-architecture was found in Indomethacin treated animals. However it was observed that, Hinguleshwar rasa showed better restoration of joint Histopathological changes occurred due to FCA damage. Hence the efficacy of Hinguleshwar rasa on Amavat (Rheumatoid arthritis) was better than Indomethacin treatment.
\end{abstract}

Key Words: Hinguleshwar rasa, Indomethacin, Histolopathology, Rheumatoid Arthritis, Amavat.

\section{Introduction}

Amavata disease is mentioned in the text Madhav nidan in Ayurveda. The symptoms of Amavata like painful swelling in the joints of hands \& feet, cervical region, girdles, stiffness etc. (1) were mentioned in the text. Rheumatoid arthritis (RA) is the most common type of autoimmune arthritis. RA causes pain and swelling in the wrist and small joints of the hand and feet. Treatment of RA may stop joint pain and swelling as well as prevents joint damage. Early treatment will give better long term results. Studies shows that people who receive early treatment for RA feel better and more often likely to lead an active life at sooner They also are less likely to have the type of joint damage that leads to joint replacement.(2) In this study investigation was made to find out the kind of preventive \& curative changes occur after oral administration of Hinguleshwar rasa and Indomethacin to FCA induced RA in paw of rat model.

* Corresponding Author:

Ajay Bapusaheb Sonawane

Ph.D (Scholar), Department of Rasashastra and Bhaishajya Kalpana, School of Ayurveda,

D Y Patil deemed to be University,

Navi Mumbai, India.

Email Id: drajaysonawane03@gmail.com

\section{Material \& Method}

The preparation of the Ayurvedic formulation Hinguleshwar rasa $(4,5)$ was carried out in Department of Rasashastra \& Bhaishajya kalpana, D Y Patil Deemed to be university Nerul, Navi Mumbai \& Tablet Indomethacin procured from local pharmacy.

Ingredients in Hinguleshwar rasa:

1. Pippali powder: $100 \mathrm{gm}$

2. Purified Hingul (Cinnabar) powder: 100gm

3. Purified Vatsanabh (Aconitum ferox L.) powder : $100 \mathrm{gm}$

Invivo FCA induced Rheumatoid arthritis (RA) study in rats was conducted at Department of Pharmacology \& Toxicology, KNP college of Veterinary Science Shirwal, Dist-Satara.

\section{Animal study}

Sprague-Dawley rats (32) were recruited in the animal study with $50 \%$ male and female ratio. All the animals were weighing $180-200$ g. which were procured from National institute of Biosciences, Bhor, Pune, after getting approval from the Institutional Animal ethics committee (IAEC), of the KNPCVS, Shirwal. Animals were transported in AC vehicle and kept for quarantine for ten days at Central laboratory Animal House of the KNP CVS Shirwal, District Satara. All the animals were apparently healthy and without any disease signs. Animals were divided into 
four groups comprising of eight animals in each. The grouping of the animals was as follows (Table 1). All the animals in each group were marked with picric acid markings for identification.

\section{Table 1}

\begin{tabular}{|l|l|l|}
$\begin{array}{l}\text { Group } \\
\text { no. }\end{array}$ & Group (n=8) & Treatment offered \\
\hline 1 & $\begin{array}{l}\text { Normal } \\
\text { control (NC) }\end{array}$ & $\begin{array}{l}\text { Normal Saline after day 14 till day } \\
28\end{array}$ \\
\hline 2 & $\begin{array}{l}\text { Disease } \\
\text { control (DC) }\end{array}$ & $\begin{array}{l}\text { FCA }(0.1 \text { ml- Sub plantar injection } \\
\text { on day 1) }\end{array}$ \\
\hline 3 & $\begin{array}{l}\text { Standard } \\
\text { (STD) }\end{array}$ & $\begin{array}{l}\text { FCA (0.1 ml- Sub plantar } \\
\text { injection) on day 1 + } \\
\text { Indomethacin }(2 \text { mg/kg p.o. from } \\
\text { day 14 onwards till day 28) }\end{array}$ \\
\hline 4 & $\begin{array}{l}\text { FCA(0.1 ml- Sub plantar injection) } \\
\text { on day 1 + Hinguleshwar Rasa } \\
\text { (Human dose converted to Rat } \\
\text { dose }=1.125 \text { mg (for 200 gm rat } \\
\text { from day 14 onwards till day } 28)\end{array}$ \\
\hline
\end{tabular}

Animals from the Group 1 received normal saline at $1 \mathrm{ml}$ /day, group 2, 3 and 4 received $0.1 \mathrm{ml} \mathrm{FCA}$ (6) and administered with $26 \mathrm{~g}$ needle in sub plantar region. Further animals of group 3 received Indomethacin at $2 \mathrm{mg} / \mathrm{kg}(7)$ orally after day 14 onwards. Animals from the group 4 received Hinguleshwar rasa at $1.125 \mathrm{mg}$ per rat.(8)

\section{Method}

Prior to the experiment, paw volume (baseline) of each animal at day 0 , was measured with vernier calliper all animals, except group 1 received sub-plantar injection of FCA $(0.1 \mathrm{ml})$ in left hind paw.

Rats were left for 14 days after the injection of FCA to allow the development of arthritis. Starting from day 14, Indomethacin and Test drug (Hinguleshwar Rasa) was administered orally till day 28 to groups 3 and 4 respectively.

At the end of the day 28, all the rats were sacrificed and ankle joints were severed and processed for histological studies.

\section{Histopathological studies}

Ankle joints were severed and processed for Histological studies, they washed with saline and fixed for $24 \mathrm{~h}$ in $10 \%$ formalin. After decalcification, the sections obtained were stained with eosin haematoxylin stain and observed under 100X magnification.

\section{Images: Observation of Histopathology of Bone tissue}

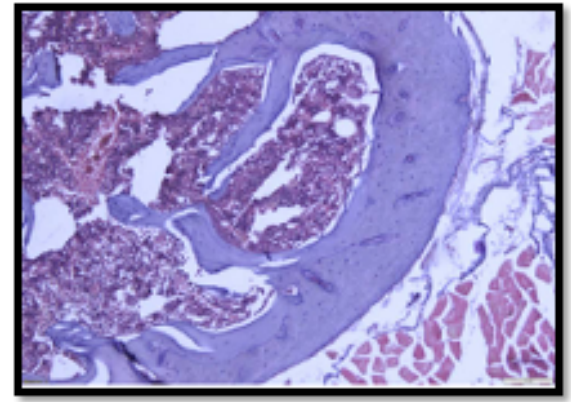

Fig.1 NC- Microphotograph of joint showing normal bone tissue, bone marrow and peri-articular tissue.

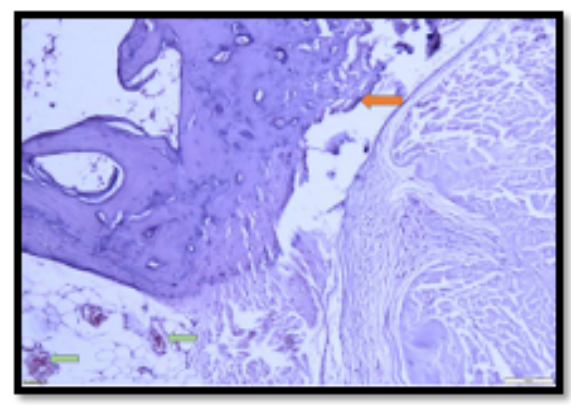

Fig.4 DC 3: Microphotograph of joint showing erosion of articular cartilage (Red arrow) with degenerative changes and congested vascular tissue (Green arrow).

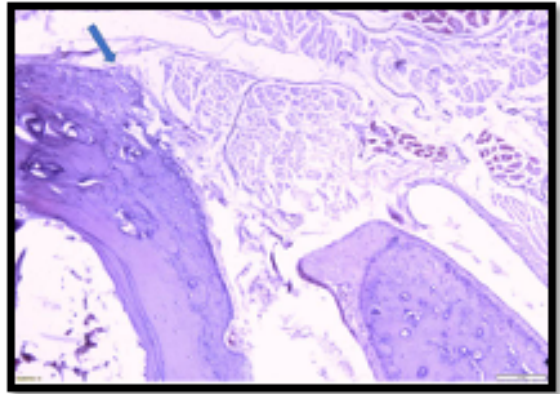

Fig.2 DC 1: Microphotograph of joint showing erosion of articular cartilage (blue arrow) with degenerative changes.

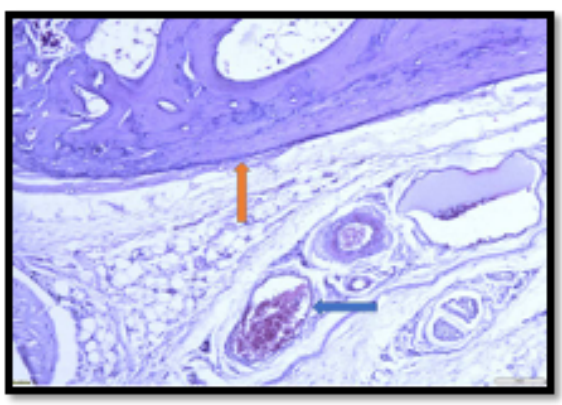

Fig.5 STD: Microphotograph of joint showing degenerative changes (red arrow) and congested vascular tissue.

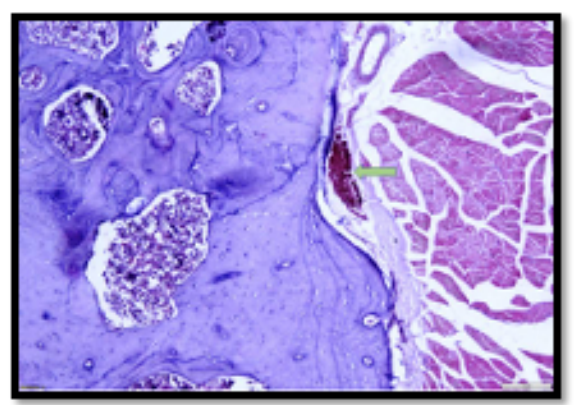

Fig.3 DC 2: Microphotograph of joint showing congested vascular tissue (Green arrow).

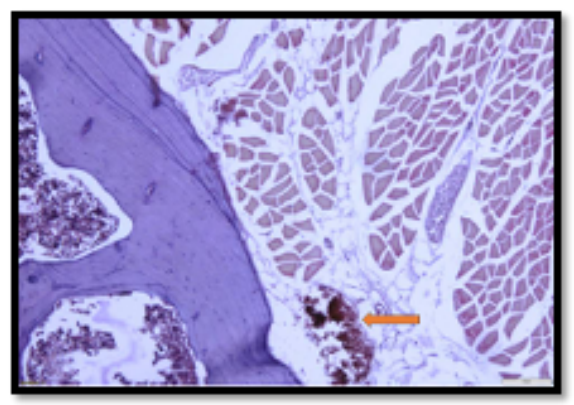

Fig.6 Test drug: Mild congested vascular tissue (red arrow). 


\section{Table 2: Histopathological Observations}

\begin{tabular}{|c|c|}
\hline $\begin{array}{c}\text { Sr. } \\
\text { No }\end{array}$ & \multicolumn{1}{|c|}{$\begin{array}{c}\text { SR No / } \\
\text { Gr Code }\end{array}$} \\
\hline 1 & $\begin{array}{l}\text { Normal Control } \\
\text { (NC) }\end{array}$ \\
\hline
\end{tabular}

2 Disease Control (DC)
The microscopic examination of tissue samples of bones from normal control group showed normal histomorphological features of Bone, Cartilage and subcutaneous tissue with muscles. Histopathological examination of joints of rats from control group did not reveal any appreciable lesions in synovial membrane, articular cartilage, joint space and bones.

Histopatholgical examination of joints from animals in group injected with CFA $(0.1 \mathrm{ml})$ in paw (negative control) revealed vascular congestion with minimal to mild infiltration of mononuclear cells (predominant lymphocytes), mild to moderate hyperplasia of synovial membrane, moderate erosion of articular cartilage. The vascular tissue in the sections showed mild congestion in the periphery of joint and muscle region.

The microscopic examination of tissue samples of bones with CFA induced arthritis and treated with Indomethacin showed mild infiltration of inflammatory cells, mild erosions in articular cartilage, and mild hyperplasia of synovial membrane. There was mild congestion of blood vessels and dilation of vascular tissue in few of the sections in the periphery of joint and muscle region.

The microscopic examination of tissue samples of bones treated with Hinguleshwar rasa, there was focal and minimal pathological changes were observed. There was focal and minimal congestion of blood vascular tissue. The bone and articular cartilage of the joints appeared intact with normal histo-architecture.

\section{Overall \\ Pathological grade}

NAD

Mild (+2)

To

Moderate

$(+3)$

Minimal (+1)

to Mild (+2)

\section{Hinguleshwar} Rasa

Note : Pathological grade codes: $\mathrm{NAD}=$ No Abnormality Detected.

Minimal (+1), Mild (+2), Moderate (+3), Severe (+4)

\section{Discussion}

Rheumatoid arthritis (RA) is a chronic systemic autoimmune disease that arises more frequently in females than males., RA primarily affects the lining of the synovial joints and can cause progressive disability. The clinical manifestations of symmetrical joint involvement include arthralgia, swelling, redness and even limiting the range of motion [3]. histopathological study shows that differences in the normal paw and FCA induced Rheumatoid arthritic rat paw. In this study histopatholgical examination of joints from animals in control group injected with CFA $(0.1 \mathrm{ml})$ in paw (negative control) revealed vascular congestion with minimal to mild infiltration of mononuclear cells (predominant lymphocytes), mild to moderate hyperplasia of synovial membrane, moderate erosion of articular cartilage and vascular tissue in the sections showed mild congestion in the periphery of joint and muscle region. In standard treatment with Indomethacin it is observed that mild infiltration of inflammatory cells, mild erosions in articular cartilage and hyperplasia of synovial membrane, mild congestion of blood vessels and dilation of vascular tissue in few of the sections in the periphery of joint and muscle region. In microscopic examination of tissue samples of bones treated with Hinguleshwar rasa, there was focal and minimal pathological changes were observed. There was focal and minimal congestion of blood vascular tissue. The bone and articular cartilage of the joints appeared intact with normal histo-architecture.
This histopathology study help to know the changes happen before and after in the paw of SD rats, results of this study reveals that as compare to Indomethacin, preventive and curative action found in Hinguleshwar rasa and it may helps in treatment of Rheumatoid Arthritis (Amavat) in humans.

\section{Conclusion}

According to the result of microscopic examination of tissue samples of bones of rats we concluded that Hinguleshwar rasa showed better restoration of joint histopathological changes occurred due to FCA damage and it show the efficacy of Hinguleshwar rasa on Amavat was better than indomethacin treatment. Hence the hypothesis of efficacy of Hinguleshwar ras on Amavat may prove.

\section{References}

1. Singhal G.D, Tripathi S.N , Sharma K.R. Ayurvedic Clinical diagnosis based on Madhav nidan part 1,published by chauhamba Sanskrit pratistan Delhi. Chapter 25, Pg.no.453-457.

2. Rheumatoid Arthritis: https:// www.rheumatology.org/I-Am-A/Patient-Caregiver/ Diseases-Conditions/Rheumatoid-Arthritis dated 23-10-2020 time 9:45 IST.

3. Review article Rheumatoid arthritis: pathological mechanisms and modern pharmacologic therapies.

4. Sadananda Sharma. Rasa tarangini, edited by Pt. Kashinath Shastry, 11th edition, 1979, published by 
Motilal Banarasidas, Varanasi. Tarang 24, Pg.no.662.

5. Ajay B. Sonawane, Archana P. Gharote, Vikas V. Karande, Comparative anti inflammatory study of Herbomineral formulation (Hinguleshwar rasa) \& Indomethacin by measuring paw volume in fca induced Rheumatoid arthritis model of rats. British journal of pharmaceutical and medical research vol.05, issue 04, pg 2515-2519, July-August 2020, 2515-2519.

6. Harith Jameel Mahdi, Nurzalina Abdul Karim Khan,Mohd Zaini Bin Asmawi, Roziahanim Mahmud,Vikneswaran A/L Murugaiyah. In vivo anti-arthritic and anti-nociceptive effects of ethanol extract of Moringa oleifera leaves on complete Freund's adjuvant (CFA)-induced arthritis in rats. Integrative Medicine Research 7 (2018) 85-94.

7. Azza A Ali, Asmaa S El-Zaitony and Ekram N Abd Al-Haleem. Evaluation of Therapeutic Efficacy of Vinpocetine in Adjuvant Induced Arthritis Model in Rats. J Pain Manage Med 2016, 2.

8. Dash P.k, Ravishankar B., A pharmacological study on the evaluation of Rasayana drugs for physiological changes in experimental model. Ayurved Darpan-Journal of Indian medicine, AprJun 2016; volume1 issue 2, 42-46. 